\title{
Ingmar Bergman on the international scene
}

\author{
Peter Cowie
}

Few Scandinavian artists, among them Ibsen, Strindberg, and Sibelius, have achieved an international renown as great as that of Ingmar Bergman. Victor Sjöström, Mauritz Stiller, and to a lesser degree Georg af Klercker established Sweden in the forefront of the silent cinema, but during an era without television, without air travel, and when films were released only in the 'civilized' countries of Western Europe and North America. Admittedly, both Sjöström and Stiller had the courage to take up residence in Hollywood, but neither man was truly at ease in America. Like Fellini, Bergman acquired his worldwide fame despite not succumbing to the siren call of the studios in Los Angeles.

Bergman's conquest of the international art-house scene must be accounted all the more remarkable because he was working in Sweden. Firstly, the Swedish language prevented him from penetrating the mainstream French or Anglo-Saxon marketplace. Secondly, as the local industry counted fewer than 10 million Swedes as the domestic audience, this meant that budgets were strictly controlled (Bergman's own salary rarely surpassed 200,000 crowns or some $\$ 35,000$ in the 1960 s). Thirdly, the star system has never existed in Scandinavia; and thus, while Godard could rely on Brigitte Bardot in Le mépris (1963), Kurosawa could count on the box-office appeal of Toshiro Mifune, and Fellini on that of Marcello Mastroianni, Ingmar Bergman was obliged to nurture his own team of gifted actors and gradually impose them on international audiences.

Fellini compared him to a medieval troubadour, who

can sit in the middle of the room and hold his audience by telling stories, doing sleight of hand. Even if you're not in full agreement with what he says, you enjoy the way he says it, his way of seeing 
the world with such intensity. He is one of the most complete cinematographic creators I have ever seen. ${ }^{1}$

Throughout the 1940s, Bergman's work was sent diligently to festivals by Svensk Filmindustri. Frenzy (1944) screened at the Mostra in Venice in 1947, while Music in Darkness featured there in 1948, Summer Interlude (1951) in 1952, and Waiting Women (1952) in 1953. A Ship Bound for India was presented at Cannes in 1947.

In September 1947, A Ship Bound for India opened in Paris, and the influential critic André Bazin wrote in Le Film Français of his admiration for the young Bergman's 'creating a world of blinding cinematic purity'. ${ }^{2}$ The next year Peter Ustinov directed a stage version of Torment (the American title of Frenzy) in London, and the same text was produced for the stage in Oslo. In the autumn of 1948, David O. Selznick, still one of the most powerful moguls in Hollywood, approached Bergman's producer Lorens Marmstedt and suggested that together they should make a screen version of Ibsen's A Doll's House, to be scripted by Bergman and directed by Alf Sjöberg. The project fell through, because Sjöberg had too many ideas, recalled Bergman, but the handsome fee enabled him to buy a high-quality $9.5 \mathrm{~mm}$ projector and prints of several Chaplin movies.

In 1952, Forsyth Hardy, the Scottish critic, wrote in his book Scandinavian Film that '[Bergman] can see and feel in film. What he decides to see and feel will greatly influence the future of the Swedish film. ${ }^{3}$

In the wake of his successes in Italy, France, and the UK, Bergman began to receive offers from abroad, from the United States, West Germany, and even from Russia. The Americans urged him to come to Hollywood to make a screen version of Turgenev's First Love. The Germans wanted to place him under contract to make $A$ Doll's House, from the play by Ibsen. But he declined all these approaches and continued to shoot his films in Sweden. ${ }^{4}$

When Sawdust and Tinsel (1953) was given a market screening during the Cannes Festival of 1954, a South American distributor

1 Interview in Playboy magazine, February 1966.

2 Peter Cowie, Ingmar Bergman: A Critical Biography, rev. edn (London: André Deutsch, 1992), p. 59.

3 H. Forsyth Hardy, Scandinavian Film (London: Falcon Press, 1952).

4 Jean Béranger, 'Rencontre avec Ingmar Bergman', Cahiers du Cinéma 15:88 (1958), 12-20. 
was impressed, and promptly flew to Stockholm to acquire it and various other Swedish titles. Two years later Bergman achieved his first major breakthrough, when Smiles of a Summer Night won the Special Jury Prize at Cannes in 1956 for 'Best Poetic Humour'. The following year he won the same award for The Seventh Seal (1957); and in 1958 Wild Strawberries (1957) was given the Golden Bear at the Berlin Film Festival, while So Close to Life (1958) brought Bergman the Best Director prize at Cannes and the three actresses in the film, Eva Dahlbeck, Ingrid Thulin, and Bibi Andersson, were given a joint award as Best Actress.

In the mid-1950s, Cyrus Harvey, president of Janus Films in New York, flew to Sweden and bought the US rights to The Seventh Seal and Wild Strawberries, establishing a relationship with Svensk Filmindustri that continues to this day. Both films attracted long queues at art houses across America, and indeed The Seventh Seal became the single most booked film on $16 \mathrm{~mm}$ at universities in the United States.

By 1959, Bergman's reputation was almost at its peak, both in the Anglo-Saxon territories and in France and Italy. Perhaps the first truly significant retrospective was the work of the British programmer and historian John Gillett who, in the summer of 1959, presented a vast series of Swedish films under the title 'The Passionate Cinema' at the National Film Theatre in London. This featured not only most of Bergman's work, but also the best films of Alf Sjöberg, Arne Mattsson, and other directors, enabling audiences to see Bergman in the context of his country's cinema. Also in 1959, The Magician (1958) or, as it was called more appropriately in Swedish, The Face (Ansiktet), won the Jury Prize for Best Direction, and it was given the Pasinetti Award by the Italian press for 'the best foreign film of 1959'.

The Academy Award for Best Foreign-language Picture went in the early months of 1960 to The Virgin Spring (1960), and the following year, Through a Glass Darkly (1961) brought Bergman his second successive Oscar in that category. The singer Harry Belafonte even declared that he wanted Bergman to make a film on the life of the Russian poet Pushkin, with Belafonte himself playing Pushkin! ${ }^{5}$

At home in Sweden, recognition was accorded Bergman by the father against whom he had reacted so violently in youth. In 1963, after seeing Winter Light, Pastor Erik Bergman wrote to him in

5 Cited in Time, 14 March 1960. 
fulsome terms: 'You will give more, far more, than what I have been capable of, reach deeper and further. This is clear to me. In grateful and humble joy. ${ }^{6}$

The Silence, released in 1963, became Bergman's most notorious film, attracting the ire of censors in various countries. In France, the censors at first declined to issue the film with the obligatory visa. The minister responsible, Alain Peyrefitte, requested certain cuts in the cabaret sequence and in the lovers' rendezvous in the hotel room. The official magazine Soviet Screen attacked Bergman sharply for the 'latent Fascism and hatred of mankind' displayed by The Silence. In West Germany, debate over the film reached the Parliament; millions of Germans queued up to see the film, making a fortune for the distributors, Atlas Film. ${ }^{7}$ This commercial success seemed to compensate for the moral opprobrium, and it may well have prompted United Artists to snap up the rights to Persona in 1966, as well as to three subsequent films, Hour of the Wolf (1968), Shame (1968), and The Passion of Anna (1969), none of which performed as well as the Americans had expected at the international box office.

Nevertheless, in 1970, ABC Pictures offered Bergman \$1 million to make The Touch (1971). He agreed to shoot it in English, but dismissed any notions of making the film in Hollywood. Once again, American investment seemed inevitably to lead to a flop. Despite this failure, in 1971 Bergman won the Irving Thalberg Award, and he sent Liv Ullmann to accept it on his behalf during the Oscar ceremony.

Bergman's successful foray into television brought him a new audience from among those who were deserting the traditional cinemas in favour of staying at home and watching the small screen. The Rite was made for television in 1969, and then, three years later, came Scenes from a Marriage. This mini-series was screened over a six-week period from 11 April to 16 May 1973 on Swedish television and subsequently on foreign channels and networks. Dubbed versions were commissioned by PBS in the United States and by the BBC in the UK, but neither proved successful. Subsequently, the series was shown in Britain with subtitles and proved more

6 Letter on display in exhibition devoted to Bergman at the Berlin Film Festival of 2011.

7 Gert H. Theunissen, Das Schweigen und sein Publikum (Cologne: Du Mont Schauberg, 1964). 
popular to home audiences. A theatrical release for a feature-length version also did well. There is little doubt that from an economic and artistic viewpoint, Scenes from a Marriage revived Bergman's reputation on both sides of the Atlantic. Indeed the torrent of revenues accruing to Bergman's production company, AB Cinematograph, enabled him to give the green light to independent film productions such as Gunnel Lindblom's Paradise Place (1977) and Kjell Grede's TV series, En dåres försvarstal (A Fake Defensive Figure, 1976). In 1974 Bergman was asked by Magnus Enhörning, the head of the music department at Sveriges Radio (SR), to direct a version of Mozart's The Magic Flute (1975), which would be aired as a premiere on television to celebrate the golden jubilee of SR. Sven Nykvist shot the film on $16 \mathrm{~mm}$, and this was then blown up to $35 \mathrm{~mm}$ for worldwide theatrical distribution.

Dino De Laurentiis, who had established his reputation and his shrewdness as a producer with the early films of Fellini, notably $\mathrm{La}$ strada in 1954 and Cabiria in 1957, had tried to woo Bergman and Svensk Filmindustri as early as 1973 . Their proposed screen version of The Merry Widow, starring Barbra Streisand, impressed De Laurentiis so much that he was willing to offer $\$ 4$ million, on condition that the film be made entirely in Sweden and that Svensk Filmindustri should assume responsibility for any increase in the budget. The project fell through, not to Bergman's chagrin. But De Laurentiis, undeterred, met secretly with Bergman in New York in February 1975 and arranged to finance the TV series Face to Face (1976). 'It's a wonderful, strong story', he declared, 'and I visualize an ideal relationship with this brilliant filmmaker. I recognize that as a creative artist Ingmar is unexcelled, and I consider myself, above all, as a showman. ${ }^{8}$

Face to Face fell to earth with a resounding thud, however, when it was shown soon after Bergman's humiliating confrontation with the Swedish tax authorities, and during the same period when, in the spring of 1976, he went into exile. This setback did not diminish Dino De Laurentiis' commitment to Bergman. Later that year, he joined Germany's Rialto Film in financing The Serpent's Egg (1977). The budget was by far the highest ever required by a Bergman production-\$3,266,000..$^{9}$ Again, however, the reception from both

8 Quoted in brochure issued by Cinema International Corporation (CIC) at Cannes for Face to Face in 1975.

9 Cowie, Ingmar Bergman, p. 314. 
critics and audiences was disappointing and, had it not been for a large number of locked-in pre-sales internationally, almost disastrous.

On 7 June 1976, Bergman made the cover of Time magazine yet again, but for the wrong reasons-'Sweden's Surrealistic Socialism' was the headline. Inside, there was a long article about the income tax situation. 'Says Ulrika Rosenberg, 23, a secretary in Botkyrka: "Bergman does not mean anything to the average Swede. He is too much above us. His films are not the films that the average Swede goes to the movies to see." 10

By the mid-1970s Bergman was attracting the attention of more producers outside Sweden. Lew Grade, the founder of ATV in the UK and a familiar, cigar-chomping figure at Cannes and other major events, would become a principal financier of both Autumn Sonata (1978) in 1977 and From the Life of the Marionettes in 1980. And yet if one looks back at Bergman's career between 1975 and 1981, it is clear that his public was deserting him. In the United States, From the Life of the Marionettes proved a flop at the box-office, perhaps all the more so because Bergman had cancelled a visit to New York, Chicago, and Los Angeles which was to have supported a campaign on behalf of Scandinavian film. Back in Sweden, the average attendance at each cinema on the film's first run was a mere sixty-four persons. In Malmö, only twelve tickets were sold at one performance. ${ }^{11}$

And this makes his renaissance with Fanny and Alexander in 1982 especially remarkable. With a massive budget of $\$ 6$ million, Fanny and Alexander could so easily have become a disaster. Instead, it enchanted audiences throughout the world, both on television and in cinemas. It grossed \$6,763,000 in the United States alone, and was rewarded with six Academy Award nominations. The film won Oscars in four categories: Cinematography, Art Direction, Costume Design, and Best Foreign-Language Film. Bergman was nominated for Best Director and for Best Original Screenplay. (He had previously been nominated as Best Director for Autumn Sonata and Face to Face.) Bergman despatched his wife Ingrid to join producer Jörn Donner on stage at the awards ceremony in Hollywood.

Serene in self-styled 'retirement', Bergman could now look back on his career with satisfaction. Rights in his memoirs, entitled The

10 Time magazine (international edition), 7 June 1976.

11 See Film og Kino (Oslo) 1 (1981). 
Magic Lantern, were sold to the United States for $\$ 500,000$, to the UK for $£ 90,000$, and to West Germany for DM400,000. The book proved a huge popular success in the Nordic countries, with 15,000 copies sold in Denmark, 48,000 in Norway, and 60,000 in Sweden, plus a further 50,000 for the Book of the Month Club in Sweden. ${ }^{12}$

On 26 November 1988, Bergman was given the European Film Academy's Lifetime Award. In his acceptance speech, he declared: 'I hope we shall never leave behind all the shadows on the screen for all these big electronic gadgets. I hope we'll never forget the mystery of those 24 frames a second. I hope we shall never deny the magic of our dreams. Long live the cinematographic art! ${ }^{13}$

In 1997 at the Cannes Festival he was given the Palme of Palmes, voted by the thirty-five living directors who had won the Palme d'Or.

By the time of his international breakthrough in the mid-1950s, Ingmar Bergman had been directing films for a full decade. Even then, not all critics shared in the applause. When Wild Strawberries appeared in the United States, Bosley Crowther, the long-established movie critic of The New York Times, wrote: 'This one is so thoroughly mystifying that we wonder whether Mr. Bergman himself knew what he was trying to say. ${ }^{14}$ Dilys Powell, the esteemed critic of the Sunday Times in London, had the temerity to write:

Mr. Bergman, I am sure, has a midnight, Arctic-winter sincerity: the violence of my dislike of his film is probably evidence of that. Did I say The Seventh Seal was sobering? On me, it has the impact of one of those spiked iron balls chained to a club, so popular in films about goodwill in the Middle Ages. ${ }^{15}$

So why was he such a godhead in the eyes of an entire generation of cinéastes and intellectuals? Why was he so successful, when many other auteurs who shared the limelight with him in the 1950s and 1960s have retreated into obscurity?

His work tapped into the zeitgeist. The Seventh Seal and Wild Strawberries emerged at the height of the Cold War. There was fear

12 See Veckans Affärer 41 (8 October 1987).

13 See www.europeanfilmawards.eu/en_EN/archive/1988 (accessed 11 March 2021).

14 The New York Times, 23 June 1959.

15 See The Sunday Times, 9 March 1958. 
of imminent nuclear annihilation, which is of course expressed metaphorically in The Seventh Seal and quite openly in Winter Light, where Max von Sydow's fisherman believes that the Chinese will develop the atom bomb and then wreak havoc on the enshrined values of our Western civilization.

The artist (or in the eyes of the down-to-earth Bergman, the entertainer) is the victim of persecution. He is regarded as subversive, a danger to established society. This was a theme that recurred in the great Bergman works of the 1960s-the humiliation of the clown Frost in Sawdust and Tinsel or of the mesmerist Vogler in The Face, not forgetting snide remarks like that of Madame Armfeldt in Smiles of a Summer Night, who says dismissively that the actors 'can sleep in the stables'. Ironically, some of these fears were revived in the year of Bergman's centenary-the fear of nuclear weapons, the sense that despite the wondrous achievements of science there is the danger of our being controlled by gigantic corporations and authorities.

All this struck a chord in those growing up in the late 1950s and early 1960s, taught as they were in the Eisenhower years, in the Erlander years, in the De Gaulle years, to wear the grey flannel suit of convention and to place order above inventiveness. A work like Summer with Monika carried a powerful charge of sexual liberation. Monika lives for each passing day and does not count the cost. One cannot help but speculate if Roger Vadim was influenced by Bergman when he made And God Created Woman (1956) just two years after Summer with Monika (1953) was released in France?

The Virgin Spring, with its graphic account of a rape in the forests of medieval Sweden, and The Silence, which showed sex in a strikingly candid way, continued to keep Bergman in the headlines and aroused the wrath of the conservative press, not to mention the censors in various countries, notably the UK and USA. When Bergman agreed to give an interview to Playboy magazine in 1964, he was simply endorsing the Anglo-Saxon view of him as a controversial and provocative auteur.

Another factor helped to establish Bergman. With the close of the 1950s, a profound intellectual revolution came into play. The French New Wave, the emergence of Fellini, Antonioni, and Visconti from Italy, the British proletarian cinema of Anderson, Schlesinger, Richardson, and Reisz, Saura in Spain, Cassavetes in New York-all this created a climate of talking and experiencing film among intellectuals and bourgeoisie alike throughout Europe and the USA. The Beatles were just around the corner. John F. Kennedy swept like a 
fresh wind into the White House. 'Art' was 'in' for the first time since the Second World War.

Bergman's influence on filmmakers was and remains considerable. Young directors envy the lucidity of his technique. Max von Sydow once said to him in print that '[f]ew directors have shown such trust in their actors, simplified the machinery around them and emphasised the human being as well as you have'. ${ }^{16}$ In 1960, Stanley Kubrick wrote in a letter to Bergman: 'Your vision of life has moved me deeply, much more deeply than I have ever been moved by any films. I believe you are the greatest film-maker at work today. ${ }^{17}$

Krzysztof Zanussi remarked that 'Bergman was for me a god. I only came to film-making because I discovered Bergman. ${ }^{18}$ Paul Verhoeven has noted that The Seventh Seal 'made me realize that films can be art. It inspired me to become a film director. This is one of the most powerful and significant films ever made. ${ }^{, 19}$ Bertrand Tavernier said that he 'did not miss a single film by Bergman', and Jean-Luc Godard wrote ecstatically about Bergman in the pages of Cahiers du Cinéma: 'Summer with Monika is the most original film of the most original of directors. It is to the cinema today what Birth of a Nation is to the classical cinema. ${ }^{, 20}$ Ecstatic, he sent Cahiers a telegram from the Berlinale in 1958: 'GOLDEN BEAR WILD STRAWBERRIES PROVES INGMAR GREATEST STOP SCRIPT FANTASTIC ABOUT FLASH CONSCIENCE VICTOR SJOSTROM DAZZLED BEAUTY BIBI ANDERSSON STOP MULTIPLY HEIDEGGER BY GIRAUDOUX GET BERGMAN STOP. ${ }^{21}$ Arnaud Desplechin, who paid tribute to Bergman's close-ups in his film A Christmas Tale (2008), has commented: 'While making a film, he is the only one whom I forbid myself to think of, otherwise I would stop everything. ${ }^{22}$ Claire Denis remembers what she felt when she saw Summer with Monika for the first time: 'I felt physically

16 See Max von Sydow, 'Vi byggde många broar', Chaplin 30:2/3 (1988), 120.

17 Letter dated 9 February 1960, lodged in the Bergman Foundation Archives, Stockholm.

18 Peter Cowie, Revolution! The Explosion of World Cinema in the '60s (London: Faber \& Faber, 2004).

19 See www.ingmarbergman.se/en/universe/bergmans-legacy (accessed 11 March 2021).

20 Quoted in Godard on Godard, translation and commentary by Tom Milne (London: Secker and Warburg, London, 1972), p. 84.

21 Godard on Godard, p. 89.

22 www.ingmarbergman.se/en/universe/bergmans-legacy (accessed 11 March 2021). 
what it is to be a young woman, this feeling of summer, youth, to be in the present. ${ }^{23}$

When directors refer to Bergman, they do not do so in terms of narrative or editing. Either it is a reference to character, as in The Right Stuff (1980) where the minister, played by Royal Dano, who trudges up to front doors to announce the death of pilots, very much evokes Bergman's humanization of Death in The Seventh Seal. Or a tribute to a particular kind of framing, like the profile shot of Lindsay Crouse in David Mamet's House of Games (1987), which is identical to that of Bibi Andersson in Persona. David Lynch also referred to Bergman's figure of Death in Lost Highway, even to the point of whitening his face.

Bergman's most devoted disciple, Woody Allen, modelled $A$ Midsummer Night's Sex Comedy (1982) as much on Smiles of a Summer Night as on A Midsummer Night's Dream. His earlier film Interiors (1978) seemed like a re-tread of Through a Glass Darkly. Allen elaborated on his admiration for Bergman:

It was a combination of three things. It was the fact that thematically, the material resonated with me so strongly. Secondly, his cinematic technique, his style, was so interesting, so intense, and so riveting to me. And the third was that his approach was poetic. It wasn't prose; it was a poetic approach. The Seventh Seal, Wild Strawberries, The Magician were really poetic films in the same sense as that, when years went by, you see in a film like Cries and Whispers - there is really very little dialogue in it. ${ }^{24}$

Other directors of different generations, from Andrei Tarkovsky to Park Chan-wook, and from John Boorman to Terry Gilliam, have acknowledged a debt to Bergman. Catherine Breillat, now celebrated for her candid studies of sexual moeurs, remembers seeing Sawdust and Tinsel at the age of twelve in Paris. 'There and then', she has written, 'I decided to become a film-maker.' 25

In 1988, one of Bergman's most iconic actresses, Eva Dahlbeck, wrote: 'In recent years Ingmar Bergman has attracted a level of interest that few living individuals ever experience. [...] Like his

23 Quoted in Trespassing Bergman, film by Jane Magnusson and Hynek Pallas (2013).

24 Gregg Kilday, 'Woody Allen Pays Tribute to Ingmar Bergman: "His Approach Was Poetic", The Hollywood Reporter, 9 February 2011.

25 See www.criterion.com/current/posts/619-sawdust-and-tinsel-awakening (accessed 11 March 2021). 
works, in the end Ingmar Bergman has come to be regarded as a unique phenomenon, many-faceted and impenetrable, sometimes debatable, always controversial. ${ }^{26}$

We should not ignore the remarkable legacy Bergman gave to the cinema through the actors and technicians whom he cherished, and who were eagerly employed by directors in other countries: Sven Nykvist, who would work with filmmakers like Tarkovsky, Woody Allen, Phil Kaufman, Bob Rafelson, and Louis Malle. Then Max von Sydow. Or Liv Ullmann, Bibi Andersson, Harriet Andersson, Ingrid Thulin, Erland Josephson, and so many others.

It is a curious paradox that Bergman had yearned to be a playwright in his youth, and failed almost completely. Not a single one of his early plays is known to audiences today. So there is a certain irony in the fact that in the decade since his death, his dramatic writing has been revived and disseminated throughout the world. Yet his finest comedy of manners, Smiles of a Summer Night, was resurrected as a musical on the Broadway stage under the title $A$ Little Night Music as long ago as 1973, with music and lyrics by Stephen Sondheim and with Len Cariou playing the role created by Gunnar Björnstrand in the movie. After 601 performances in New York, it travelled across the United States and around the globe, becoming a staple of the repertory scene. A Little Night Music became a film, starring none other than Elizabeth Taylor, directed by Harold Prince in 1977. This leads to a further paradox: Bergman's stage productions were memorable events in the Swedish cultural landscape, but only a handful ever travelled abroad (Urfaust, Hedda Gabler, and Hamlet to London, for example, and Hamlet and Miss Julie to New York); theatres around the world have programmed stage versions of his films and screenplays, such as Scenes from a Marriage and even Persona.

Bergman's status as an international phenomenon may have reached its zenith with the release of Fanny and Alexander; but in the quarter of a century between that film and his death in 2007, he was seldom left in obscurity. He continued to make films for television until 2002, and the faithful trekked to his beloved island of Fårö to pay their respects during 'Bergman Week', launched in 2004. His major films were constantly reissued in home-video formats, from VHS to laser disc, from DVD to Blu-ray. The final accolade

26 Eva Dahlbeck, 'Några funderingar kring en arbetskamrat på väg att kanoniseras', Chaplin 30:2/3 (1988), 116. 
came in the centennial year of his birth on 14 July 1918, with a vast array of events, screenings, and stage productions. Bergman still seems capable of beguiling foreign directors, as witnessed by Margarethe von Trotta's Searching for Ingmar Bergman (2018) and Mia Hansen-Løve's Bergman Island (2021), featuring Tim Roth, Vicky Krieps, and Mia Wasikowska.

Alejandro González Iñárittu, director of the Academy Awardwinning Birdman (2014) and The Revenant (2015), has commented about Bergman's island of Fårö, albeit somewhat extravagantly, '[i]f cinema was a religion, this would be Mecca, the Vatican. This is the centre of it all. ${ }^{27}$

How, finally, did his international fame affect Bergman and his work? He certainly took more risks in terms of form and, on occasion, of content. He could afford to live on Fårö and make his films almost without telling Svensk Filmindustri what they would be like, other than a quick call to the president, Kenne Fant. Often the title of the film would be decided only at the last moment.

Two months after his passing in 2007, the number of references to 'Bergman and film' on Google amounted to 2.80 million. For Fellini, it was 2.10 million, for Kurosawa 2.08 million, for Welles 2.06 million, for Antonioni 2.05 million, and for Godard 1.70 million. A random exercise, no doubt, but one that suggested that Bergman was not about to fade from sight. True, revisionist articles had begun to appear, at first in august magazines like Sight and Sound and then, brutally, in the days following Bergman's death, in The New York Times. There Jonathan Rosenbaum savaged his reputation in a piece entitled 'Scenes from an Overrated Career'. Rosenbaum accused Bergman of being theatrical instead of cinematic and, bizarrely, of having the power to entertain, which directors like Bresson and Dreyer lacked. Therefore, according to Rosenbaum, Bergman failed to challenge 'conventional film-going habits'. ${ }^{28}$

The fact remains that, as the critic Mikael Timm has acknowledged,

audience reactions and reviews show that Bergman's work has an impact on people from other cultures in an apparently straightforward way. Bergman stands with both feet in the mainstream European cultural tradition, and this is a common platform for many

27 Quoted in Trespassing Bergman.

28 Quoted in The New York Times, 4 August 2007. 
people - regardless of what language they speak. [...] Like Shakespeare's England, Bergman's Sweden is a stage. ${ }^{29}$

And over a period of almost sixty years, Bergman enveloped cultural thinking to the point that his Swedish stage became, in effect, that of the world.

29 Mikael Timm, 'A Filmmaker in the Borderland: Bergman and Cultural Traditions', Chaplin 30:2/3 (1988), 95. 